\title{
Minireview
}

nephron

Clinical

Practice

\section{Nutritional Therapy, Phosphate Control and Renal Protection}

\author{
Juan Jesús Carrero ${ }^{\mathrm{a}}$ Mario Cozzolino $^{\mathrm{b}}$ \\ ${ }^{a}$ Division of Nephrology and Center for Molecular Medicine, Karolinska Institute, Stockholm, Sweden; \\ ${ }^{b}$ Department of Health Sciences, Renal Division, San Paolo Hospital, University of Milan, Milan, Italy
}

\section{Key Words}

Chronic kidney disease $\cdot$ Phosphate $\cdot$ Nutrition

\begin{abstract}
Dietary management of chronic kidney disease (CKD) focusses on limiting the intake of substances that might accumulate to toxic levels (such as potassium, phosphorus or salt) and, although still a matter of debate for some, restricting dietary protein to retard kidney damage. Recent evidence brings the opportunity to revisit the role of a healthy diet on disease progression and on some of the cardiometabolic complications of moderate/advanced CKD, such as inflammation or oxidative stress control. This review provides a brief overview of dietary strategies that delay CKD progression and CKD complications, and discusses currently limited data addressing the development of malnutrition and protein-energy wasting before dialysis initiation.
\end{abstract}

(c) 2014 S. Karger AG, Basel

\section{Introduction}

The kidney plays an essential role in nutrient homeostasis and electrolyte and fluid control. Thus, the presence of reduced kidney function and development of chronic kidney disease $(\mathrm{CKD})$ requires specific dietary adapta- tions. Some of these adaptations are focused on avoiding the retention of specific micro- and macronutrients to toxic levels. Other approaches seek to retard kidney damage and slow progression to end-stage renal disease (ESRD). Finally, the increased prevalence of malnutrition in advanced CKD stages provides another scenario for dietary modification. This review aims at offering a general overview of current dietary recommendations in nondialyzed CKD patients before the start of dialysis.

\section{Nutritional Considerations for Halting CKD Progression}

The evidence that lifestyle factors may be involved in the incidence and progression of CKD is mounting. Protein restrictive diets have been the subject of much research and debate, and the inevitable link between salt intake and hypertension demands salt control in patients with reduced renal function. In addition, modern nutritional epidemiology has identified other unhealthy dietary habits that may be associated with the development of CKD. When interpreting the following studies, it should be emphasized, however, that modifying dietary habits is challenging and implies a major change in lifestyle. Indeed, it may be more difficult to implement and evaluate dietary than drug interventions.

\section{KARGER}

E-Mail karger@karger.com www.karger.com/nec
C 2014 S. Karger AG, Basel

$1660-2110 / 14 / 1261-0001 \$ 39.50 / 0$
Mario Cozzolino, $\mathrm{MD}, \mathrm{PhD}$

Renal Division and Laboratory of Experimental Nephrology

Dipartimento di Scienze della Salute, Università di Milano

Via A. di Rudinì 8, IT-20142 Milan (Italy)

E-Mail mario.cozzolino@unimi.it 


\section{Low-Protein Diets}

Animal studies from the 1960s showed that a highprotein diet results in glomerular hyperfiltration and subsequent kidney injury [1], and population-based cohorts seem to confirm these deleterious effects of high intake of nondairy animal protein on renal function [2]. Thus, it is generally recommended that excessive protein intake be avoided by individuals with $\mathrm{CKD}$, and moderate restriction on dietary protein is advocated. The latest KDIGO guidelines suggest the consumption of a high-quality protein diet of around $0.8 \mathrm{~g} / \mathrm{kg} /$ day among those individuals with CKD stages 3-5 who are highly motivated to follow such a diet [3]. Other recommendations suggest a lower range of protein restriction to $0.6-0.8 \mathrm{~g} / \mathrm{kg} / \mathrm{day}$, provided that signs of malnutrition are not present [4].

Whether patients with CKD should be prescribed a restricted dietary protein has been a matter of much debate. The largest randomized controlled trial (RCT) performed to date, the Modification of Diet in Renal Diseases (MDRD) study, included about 600 individuals with moderate CKD and showed that a low- versus usualprotein diet ( $0.58 \mathrm{vs.} 1.3 \mathrm{~g} / \mathrm{kg} /$ day) did not result in slower decline of kidney function [5]. Other smaller RCTs showed that protein restriction to approximately $0.6-0.8$ $\mathrm{g} / \mathrm{kg} /$ day was associated with a modest and not significant benefit on CKD progression $[6,7]$. In clinical trials including insulin-dependent diabetic nephropathy patients, low-protein diets (LPDs) resulted in slower decline of glomerular filtration rate (GFR) [8,9]. A meta-analysis that involved about 1,500 patients suggested a 39\% lower risk of kidney failure or death in patients randomly assigned to LPD [10]. A more recent systematic review meta-analyzed studies specifically addressing patients with CKD stages 1-3 and found no reduction in mortality or ESRD after an LPD [11]. Differences in the inclusion criteria, degree of proteinuria or type of protein provided may have affected the results of the studies mentioned above. Because present data are not firmly conclusive, dietary protein restriction cannot be recommended as a routine kidney protective strategy for patients with $\mathrm{CKD}$. However, the reported safety of LPDs and their beneficial effects on uremic symptoms are obvious and justify its prescription for most CKD patients.

One concern regarding LPDs is that they might compromise nutritional status in the long term, especially in those individuals with concurrent conditions that would require higher amounts of proteins such as infections, metabolic acidosis or other procatabolic states. Despite this common concern, RCTs show that a LPD does not seem to result in malnutrition [5-7], though patients in studies are subjected to more stringent dietary counseling and control than is common in clinical practice. Monitoring of nutritional status must therefore be implemented if protein-restricted diets are prescribed. Adequate caloric intake must be ensured and at least $60 \%$ of the ingested protein must be of high biologic value or contain a high percentage of essential amino acids to ensure net neutral nitrogen balance. Because dietary protein is a source of metabolic acids that stimulate skeletal muscle protein breakdown, LPDs may be associated with less metabolic acidosis. If the patients appear to be at risk of malnutrition, the LPD can be supplemented with essential amino acids and/or keto acids. The use hypercaloric renal-specific supplements in the context of an LPD has been associated with protein intake closer to the target values, better nutritional measures and better adherence to therapy than an LPD alone [12]. Likewise, ketoanalogues of essential amino acids (keto acids) can also be used based on their capacity to neutralize the excessive nitrogen residues through transamination and limit the production of urea, thus breaking the vicious cycle of the disease while at the same time allowing the preservation of nutritional status [13]. It has been postulated that besides the amount of dietary protein, the source of protein could also be important and that vegetable protein or egg whites are preferable $[14,15]$. Vegetable sources of protein might have additional benefits that motivate its recommendation in CKD patients such as lower organic phosphorus absorption and, consequently, lower serum phosphate levels and decreased fibroblast growth factor-23 [16]. Vegetarian diets may also decrease the production of uremic toxins such as p-cresyl sulfate and indoxyl sulfate [17], which have been implicated in CKD progression [18]. Finally, a diet high in vegetables might lead to lower endogenous production of acid [19].

Adherence to a protein diet with $0.6 \mathrm{~g} / \mathrm{kg} /$ day of proteins is often difficult. Nutritional education programs and dietitians' advice are effective in increasing patient adherence to low-protein intake recommendations [20]. The support of the patient by family members and whoever prepares the food is also critical. To maintain this change over time, the LPD prescribed has to be pleasant, varied and not too restrictive. A recent Italian study proposed a simplified approach to an LPD feasible for the patients and for implementation in the clinic [21]. The authors proposed to their patients a simplified vegetarian LPD supplemented with ketoanalogues. The simplified diet was based on a concept of forbidden and allowed foods [forbidden: fish, meat, milk, eggs and derivatives (except in the context of the free-choice meals); every- 
thing else is allowed]. The diet was essentially vegan, with an average protein intake of $0.6 \mathrm{~g} / \mathrm{kg} / \mathrm{day}$ and an average energy intake of $30-35 \mathrm{kcal} / \mathrm{kg} /$ day, supplemented with ketoanalogues. To improve compliance, $1-3$ free-choice meals per week were allowed and the foods are not weighed. Adherence and feasibility were good and the findings were able suggest an easier method to achieve dietary protein restriction.

\section{Salt Restriction}

High dietary sodium is an important determinant of blood pressure, predisposing patients with established CKD to salt-sensitive hypertension and fluid retention. Higher dietary sodium intake has been associated with GFR decline in the community [22]. Dietary salt restrictive approaches like the DASH diet [23] are effective in reducing blood pressure. However, there is presently no evidence that a reduction of dietary sodium will retard $\mathrm{CKD}$ progression. In individuals with $\mathrm{CKD}$, sodium restriction has been shown to enhance the effects of various antiproteinuric drugs such as angiotensin receptor blockers [24]. More interestingly, an interventional study [25] assigned 176 patients with nondialyzed hypertensive $\mathrm{CKD}$ to a low-sodium diet $(2,300 \mathrm{mg} /$ day $)$ over 7 days, and reported (vs. a control group) that sodium restriction resulted in a greater reduction in blood pressure as well as a reduction in urine protein excretion. Despite these encouraging findings, intensive reduction in dietary sodium may be difficult to achieve due to poor adherence. The main reasons for poor adherence are (1) worse taste/ palatability of low-sodium foods, (2) availability and cost of low-sodium foods, (3) interference with socialization, and (4) lack of perceived benefit and inability to identify low sodium foods. The advice and follow-up of nutritionists is probably needed to improve patient motivation and compliance. Current guidelines recommend an upper limit of $2-3 \mathrm{~g}$ of salt per day in nondialyzed CKD patients for blood pressure and volume control as well as for improving the efficacy of antiproteinuric medication [26, 27].

\section{Other Beneficial Dietary Approaches}

Recent studies suggest additional potential benefits of healthy eating on CKD progression. In the community, individuals consuming too much saturated fat are more likely to progress to CKD [22]. In those with manifest CKD, a meta-analysis of RCTs addressing the impact of n-3 polyunsaturated fatty acids (present in fish oil) on proteinuria and renal function reported a greater reduction in urine protein excretion with this dietary interven-

Modified GPS in Colorectal Cancer in the Era of Targeted Therapy tion [28]. When recommending fish intake to CKD patients, however, knowledge of the phosphate-to-protein ratio in different fish species is recommended. Growing evidence suggests potential benefit of dietary fat modification strategies in CKD patients, including increasing the amount of linoleic acid (n-6 PUFA) from vegetable oils and thus reducing the amount of saturated fat ingested $[29,30]$.

A high consumption of sugary drinks/sodas has been associated with the incidence of albuminuria, CKD and faster GFR decline in the community [31, 32]. However, there is no evidence from interventional studies to support these observational data. An RCT in people with CKD stages 2-3 reported that a low-fructose diet was able to significantly reduce a number of inflammatory biomarkers and blood pressure versus a control group consuming their habitual fructose intake [33]. A recent study found that lower fiber intake was associated with elevated serum CRP levels and increased mortality in people with CKD [34]. Hypovitaminosis D has also been associated with ESRD initiation in people with CKD stages 4-5, an association that is explained in part by fibroblast growth factor-23-dependent pathways [35]. In a series of RCTs, a higher intake of fruits and vegetables was compared to the efficacy of oral bicarbonate in people with CKD stages $1-4$. The rationale was that high-alkali fruit intake would reduce the dietary acid load and be able to control acidosis and subsequent kidney injury. In CKD stage 2, both treatments attenuated kidney injury to a similar extent [36]. In CKD stages 3-4, metabolic acidosis was significantly reduced by both treatments (although, as expected, more in the bicarbonate group) [37]. With increasedbutcontrolledfruit/vegetableintake, hyperkalemia was not induced [37].

All these associations between healthy nutrients and CKD may be the result of healthy eating in general. Consistent with this notion, increased urine albumin excretion and higher odds of rapid decline in estimated GFR rate have been reported among individuals with consistent Western dietary patterns [2]. In a population-based study, greater adherence to a Mediterranean diet was associated with lower odds of current CKD and was a predictor of mortality in those with manifest CKD [38]. Finally, a healthy diet is often accompanied by other healthy habits that may impact on kidney function. A recent study showed that adherence to a healthy lifestyle (assessed on the basis of smoking habits, BMI, physical activity and dietary quality) was associated with lower allcause mortality risk in people with CKD stage 3 or more advanced [39]. 


\section{Phosphate Control and CKD Progression}

Because organic phosphorus is bound to protein, the amount of protein eaten will predictably determine phosphorus intake. The intestinal absorption of organic phosphorus is lower if coming from animal sources (absorbed by $40-60 \%$ ) than from vegetable sources (absorbed by 10 $30 \%$ ). However, inorganic phosphorus presently added to processed foods is almost entirely absorbed in the intestine. Because the amounts of inorganic phosphorus are often not reported in processed food labels, estimation of the real phosphorus intake of $\mathrm{CKD}$ patients is challenging and likely exceeds recommendations. Since there are physiological adaptations to counteract excessive phosphorus retention, hyperphosphatemia typically occurs only when patients reach CKD stages $4-5$ [40]. This means that dietary phosphorus restriction is generally not necessary in earlier stages. In CKD stage $4-5$, elevated phosphate levels were reported to be direct predictors of mortality [41]. Current recommendations for phosphorus intake in CKD stages 3-5 are to reduce intake to $800-1,000$ $\mathrm{mg} /$ day, in conjunction with use of phosphate binders if considered necessary [4]. Although noncontrolled evidence is not unanimous in this regard, a recent RCT suggested that a low-phosphorus diet is able to decrease serum phosphorus and fibroblast growth factor-23 levels [42]. Another recent RCT showed that the combined prescription of this diet and phosphate binders proved to be more effective than each of these approaches alone [43]. Whenever serum phosphorus is high, regardless of the CKD stage, it seems reasonable to restrict phosphorus intake in addition or not to phosphorus binder prescription.

By reducing the amount of dietary phosphorus absorbed from the gut, phosphate binders help to control serum phosphorus levels and are used by $70-90 \%$ of patients receiving hemodialysis in Europe [44]. Clinical trials have confirmed that phosphate binders effectively reduce serum phosphorus in healthy participants, patients not yet undergoing dialysis and patients receiving longterm dialysis for ESRD $[45,46]$. Thus, it has been proposed that people with CKD may receive phosphate binders before dietary restrictions are advised. This could help to control serum phosphorus while maintaining highprotein intake and good nutrition, thus avoiding the potential for protein-energy wasting (PEW) and increased mortality associated with protein restriction. In support of this, the Dialysis Outcomes and Practice Patterns Study (DOPPS) showed that phosphate binder use was associated with improved survival and better nutritional status [47], perhaps due to a more liberal diet as allowed by phosphate binder use. Prospective interventional studies are needed to confirm these observational data.

Studies have shown that the use of sevelamer- or lanthanum-based phosphate binders can greatly reduce the occurrence of calcification in laboratory models of chronic renal failure. For example, studies of rat vascular smooth muscle cells illustrate that the presence of phosphorus increases the incidence of calcification, and that lanthanum can attenuate this increase [48]. Treatment of rats with chronic renal failure with $3 \%$ sevelamer or with 3\% lanthanum carbonate reduced the calcification of aortic root lesions to a similar extent [48]. Sevelamer or lanthanum carbonate treatment has been shown to attenuate the development of coronary and aortic calcifications in patients on maintenance hemodialysis to a greater extent than treatment with calcium-based phosphate binders [49]. Two recent studies have shown a similar effect with lanthanum carbonate [50,51]. However, these potential benefits have not been associated with improved survival in large RCTs.

Phosphorus overload may be detrimental to the cardiovascular prognosis in CKD. Nevertheless, no clinical trial has yet demonstrated that reducing phosphorus intake improves survival in nondialyzed CKD patients or reduces $\mathrm{CKD}$ progression. The use of phosphate binders in CKD is based on observational rather than clinical trial data. The few studies available suggest a limited effect of phosphate binders, at least when used in 'normophosphatemic' patients and not in combination with diet [52]. Furthermore, considering the limitations of available studies, more clinical trials and follow-up analyses should investigate the impact of phosphorus metabolism management (nutritional interventions and phosphate binder use) on outcomes at different serum phosphate levels and renal function.

Because oral calcium carbonate affects calcium but not phosphorus balance in CKD stages 3-4 [53], and administration of calcium-containing phosphate binders in hemodialysis patients is associated with increased vascular calcification [54], concern has been raised regarding the safety of excess calcium intake in nondialyzed individuals with CKD. In a calcium balance study, normal individuals and patients with CKD stages 3-4 were in slightly negative to neutral calcium balance on an $800-\mathrm{mg} /$ day calcium diet [55]. Normal individuals were in modest positive calcium balance on a 2,000-mg/day diet, whereas CKD patients on the same diet were in marked positive calcium balance. Furthermore, increased calcium intake significantly decreased 1,25-dihydroxyvitamin D and PTH levels, but it did not alter the serum calcium concentration. On the basis of this study, a diet of 2,000 mg/day of calcium in CKD patients might result in a positive calcium balance with the extra
Carrero/Cozzolino 
calcium deposited in tissues leading to calcification. Therefore, it seems reasonable to restrict total calcium intake to the currently recommended dose of $1,500 \mathrm{mg} /$ day [56].

\section{Malnutrition in Patients with Nondialyzed CKD}

Complications involving protein-energy status are relatively common in ESRD stages and are associated with poor outcomes and disability. These complications have been collectively termed as PEW. The term PEW was developed in recognition that not all causes of wasting are due to inadequate nutrient intake. PEW is defined as abnormally low levels or excessive losses of body protein mass and energy reserves. Causes of PEW thus include inadequate nutrient intake, but also increased catabolism as induced by systemic inflammation, oxidative stress, imbalance in anabolism/catabolism, metabolic acidosis, abnormal glucose and insulin homeostasis, and vitamin $\mathrm{D}$ deficiency $[57,58]$. Recently, the role of male hypogonadism (i.e. testosterone deficiency) in nondialyzed CKD patients has attracted renewed attention [59] not only owing to its association with reduced muscle mass and strength [60], but also endothelial dysfunction and risk of cardiovascular events prior to dialysis initiation [61]. Many of these conditions start to become especially apparent in people with CKD when reaching stages 4 and 5 . A decline in protein and energy intake is often followed by a worsening in nutritional status. An important aspect to consider in nutritional intake is the content of other nutrients in ingested foods. The dietary restrictions discussed above are necessary in CKD to control hyperkalemia, hyperphosphatemia, and calcium or sodium balance. However, if these restrictions are not accompanied by counseling on alternative food choices, they may result in nutritional deficiencies and appearance of malnutrition. Relatively few studies have addressed the prevalence of malnutrition in nondialyzed CKD patients. Studies defining malnutrition on the basis of hypoalbuminemia report a prevalence of $20-45 \%[62,63]$. Studies defining malnutrition on the basis of diagnostic tools like subjective global assessment report a prevalence of 18-20\% [6466]. Thus, it is reasonable to state that likely 1 out of 5 people with CKD stages 4-5 will develop PEW prior to initiation of dialysis. The topic of screening and diagnosis of PEW in nondialyzed CKD is not covered in this review, but has been discussed elsewhere [4, 67]. An opinionbased algorithm for clinical assessment and management of malnutrition in nondialyzed CKD has recently been proposed [68].

Modified GPS in Colorectal Cancer in the Era of Targeted Therapy
A critical aspect of malnutrition management in predialysis stages is the amount of energy ingested. Neutral or positive nitrogen balance requires adequate energy intake, and a low-energy intake may directly cause PEW. It is recommended that the daily energy intake in nondialyzed CKD patients be approximately $35 \mathrm{kcal} / \mathrm{kg} /$ day in those aged $<60$ and $30 \mathrm{kcal} / \mathrm{kg} / \mathrm{day}$ in those aged $\geq 60$ years [56]. These recommendations for energy intake may be modified when examination of an individual's daily energy expenditure indicates different needs. When signs of malnutrition are present, the use of nutritional supplements may be indicated. However, the use of traditional supplements (protein-rich) may be counterintuitive if we advocate an LPD to avoid kidney damage. Hypercaloric supplements providing essential amino acids but with low-protein content could theoretically have some advantages versus traditional supplements, but are more expensive. Unfortunately, no interventional trials of nutritional support in malnourished patients with nondialyzed CKD have yet been published.

\section{Conclusion}

Nutrient intake is likely to influence the risk for initiation and progression of CKD as well as some of its associated complications. The evidence linking nutrition with occurrence and prognosis of CKD is unfortunately variable and many nutrients have not been thoroughly investigated. Some topics like salt control and protein restriction have more solid evidence to support their use in clinical practice. However, in the context of present dietary trends, it may not be easy for patients to comply with such restrictions. To date, very little evidence exists on how to manage malnutrition in nondialyzed CKD. Education on nutritional approaches and adaptations in the context of CKD must be a part of patient management at both early and advanced stages. Such programs benefit from the expertise and dedication of nutritionists and dietitians, contributing positively to patient motivation and adherence.

\section{Disclosure Statement}

J.J.C. acknowledges grant support from the Swedish Research Council and the Centre for Gender Medicine at the Karolinska Institute, as well as speaker engagements for Abbott Nutrition and Shire. M.C. has received research grants from Shire and Takeda, and speaker engagements for Abbott, Shire, Amgen, Genzyme, and Roche, and has participated on advisory boards for Abbott, Amgen, Shire, Genzyme, Vifor Fresenius, and Novartis.

Nephron Clin Pract 2014;126:1-7 DOI: $10.1159 / 000357679$ 


\section{References}

$>1$ Brenner BM, Meyer TW, Hostetter TH: Di- 12 Montes-Delgado R, Guerrero Riscos MA, etary protein intake and the progressive nature of kidney disease: the role of hemodynamically mediated glomerular injury in the pathogenesis of progressive glomerular sclerosis in aging, renal ablation, and intrinsic renal disease. N Engl J Med 1982;307:652-659.

2 Lin J, Fung TT, Hu FB, Curhan GC: Association of dietary patterns with albuminuria and kidney function decline in older white women: a subgroup analysis from the Nurses' Health Study. Am J Kidney Dis 2011;57:245-254.

$\checkmark 3$ Stevens PE, Levin A, Kidney Disease: Improving Global Outcomes Chronic Kidney Disease Guideline Development Work Group M: Evaluation and management of chronic kidney disease: synopsis of the kidney disease: improving global outcomes 2012 clinical practice guideline. Ann Intern Med 2013;158:825-830.

-4 Ikizler TA, Cano NJ, Franch H, Fouque D, Himmelfarb J, Kalantar-Zadeh K, Kuhlmann MK, Stenvinkel P, Terwee P, Teta D, Wang AY, Wanner C: Prevention and treatment of protein energy wasting in chronic kidney disease patients: a consensus statement by the International Society of Renal Nutrition and Metabolism. Kidney Int 2013;84:1096-1107.

$>5$ Klahr S, Levey AS, Beck GJ, Caggiula AW, Hunsicker L, Kusek JW, Striker G: The effects of dietary protein restriction and blood-pressure control on the progression of chronic renal disease. Modification of Diet in Renal Disease Study Group. N Engl J Med 1994;330:877-884.

6 Aparicio M, Chauveau P, De Precigout V, Bouchet JL, Lasseur C, Combe C: Nutrition and outcome on renal replacement therapy of patients with chronic renal failure treated by a supplemented very low protein diet. J Am Soc Nephrol 2000;11:708-716.

$>7$ Bernhard J, Beaufrere B, Laville M, Fouque D: Adaptive response to a low-protein diet in predialysis chronic renal failure patients. J Am Soc Nephrol 2001;12:1249-1254.

$>8$ Walker JD, Bending JJ, Dodds RA, Mattock MB, Murrells TJ, Keen H, Viberti GC: Restriction of dietary protein and progression of renal failure in diabetic nephropathy. Lancet 1989;2:1411-1415.

$>9$ Zeller K, Whittaker E, Sullivan L, Raskin P, Jacobson HR: Effect of restricting dietary protein on the progression of renal failure in patients with insulin-dependent diabetes mellitus. N Engl J Med 1991;324:78-84.

10 Fouque D, Laville M: Low protein diets for chronic kidney disease in non diabetic adults. Cochrane Database Syst Rev 2009;3: CD001892.

$\checkmark 11$ Fink HA, Ishani A, Taylor BC, Greer NL, MacDonald R, Rossini D, Sadiq S, Lankireddy S, Kane RL, Wilt TJ: Screening for, monitoring, and treatment of chronic kidney disease stages 1 to 3: a systematic review for the U.S. Preventive Services Task Force and for an American College of Physicians clinical practice guideline. Ann Intern Med 2012;156: 570-581. Garcia-Luna PP, Martin Herrera C, Pereira Cunill JL, Garrido Vazquez M, Lopez Munoz I, Suarez Garcia MJ, Martin-Espejo JL, Soler Junco ML, Barbosa Martin F: Treatment with low-protein diet and caloric supplements in patients with chronic kidney failure in predialysis. Comparative study (in Spanish). Rev Clin Esp 1998;198:580-586.

13 Mircescu G, Garneata L, Stancu SH, Capusa C: Effects of a supplemented hypoproteic diet in chronic kidney disease. J Ren Nutr 2007;17: 179-188.

14 Kontessis P, Jones S, Dodds R, Trevisan R, Nosadini R, Fioretto P, Borsato M, Sacerdoti D, Viberti G: Renal, metabolic and hormonal responses to ingestion of animal and vegetable proteins. Kidney Int 1990;38:136-144.

15 Nakamura H, Ito S, Ebe N, Shibata A: Renal effects of different types of protein in healthy volunteer subjects and diabetic patients. Diabetes Care 1993;16:1071-1075.

16 Moe SM, Zidehsarai MP, Chambers MA, Jackman LA, Radcliffe JS, Trevino LL, Donahue SE, Asplin JR: Vegetarian compared with meat dietary protein source and phosphorus homeostasis in chronic kidney disease. Clin J Am Soc Nephrol 2011;6:257-264.

17 Patel KP, Luo FJ, Plummer NS, Hostetter TH, Meyer TW: The production of p-cresol sulfate and indoxyl sulfate in vegetarians versus omnivores. Clin J Am Soc Nephrol 2012;7:982-988.

18 Wu IW, Hsu KH, Lee CC, Sun CY, Hsu HJ, Tsai CJ, Tzen CY, Wang YC, Lin CY, Wu MS: p-Cresyl sulphate and indoxyl sulphate predict progression of chronic kidney disease. Nephrol Dial Transplant 2011;26:938-947.

19 Goraya N, Wesson DE: Dietary management of chronic kidney disease: protein restriction and beyond. Curr Opin Nephrol Hypertens 2012;21:635-640.

20 Paes-Barreto JG, Silva MI, Qureshi AR, Bregman R, Cervante VF, Carrero JJ, Avesani CM: Can renal nutrition education improve adherence to a low-protein diet in patients with stages 3 to 5 chronic kidney disease? J Ren Nutr 2013;23:164-171.

21 Piccoli GB, Ferraresi M, Deagostini MC, Vigotti FN, Consiglio V, Scognamiglio S, Moro I, Clari R, Fassio F, Biolcati M, Porpiglia F: Vegetarian low-protein diets supplemented with keto analogues: a niche for the few or an option for many? Nephrol Dial Transplant 2013;28:2295-2305.

22 Lin J, Hu FB, Curhan GC: Associations of diet with albuminuria and kidney function decline. Clin J Am Soc Nephrol 2010;5:836-843.

23 Sacks FM, Svetkey LP, Vollmer WM, Appel LJ, Bray GA, Harsha D, Obarzanek E, Conlin PR, Miller ER 3rd, Simons-Morton DG, Karanja N, Lin PH: Effects on blood pressure of reduced dietary sodium and the Dietary Approaches to Stop Hypertension (DASH) diet. DASH-Sodium Collaborative Research Group. N Engl J Med 2001;344:3-10.
24 Lambers Heerspink HJ, Holtkamp FA, Parving $\mathrm{HH}$, Navis GJ, Lewis JB, Ritz E, de Graeff PA, de Zeeuw D: Moderation of dietary sodium potentiates the renal and cardiovascular protective effects of angiotensin receptor blockers. Kidney Int 2012;82:330-337.

25 Yu W, Luying S, Haiyan W, Xiaomei L: Importance and benefits of dietary sodium restriction in the management of chronic kidney disease patients: experience from a single Chinese center. Int Urol Nephrol 2012;44: 549-556.

26 Levin A, Hemmelgarn B, Culleton B, Tobe S, McFarlane P, Ruzicka M, Burns K, Manns B, White C, Madore F, Moist L, Klarenbach S, Barrett B, Foley R, Jindal K, Senior P, Pannu N, Shurraw S, Akbari A, Cohn A, Reslerova M, Deved V, Mendelssohn D, Nesrallah G, Kappel J, Tonelli M: Guidelines for the management of chronic kidney disease. CMAJ 2008;179:1154-1162.

27 Fouque D, Vennegoor M, ter Wee P, Wanner C, Basci A, Canaud B, Haage P, Konner K, Kooman J, Martin-Malo A, Pedrini L, Pizzarelli F, Tattersall J, Tordoir J, Vanholder R: Ebpg guideline on nutrition. Nephrol Dial Transplant 2007;22(Suppl 2):ii45-ii87.

-28 Miller ER 3rd, Juraschek SP, Appel LJ, Madala M, Anderson CA, Bleys J, Guallar E: The effect of n-3 long-chain polyunsaturated fatty acid supplementation on urine protein excretion and kidney function: meta-analysis of clinical trials. Am J Clin Nutr 2009;89:1937-1945

29 Huang X, Stenvinkel P, Qureshi AR, Cederholm T, Barany P, Heimburger O, Lindholm B, Riserus U, Carrero JJ: Clinical determinants and mortality predictability of stearoylCoA desaturase- 1 activity indices in dialysis patients. J Intern Med 2013;273:263-272.

30 Huang X, Stenvinkel P, Qureshi AR, Riserus U, Cederholm T, Barany P, Heimburger O, Lindholm B, Carrero JJ: Essential polyunsaturated fatty acids, inflammation and mortality in dialysis patients. Nephrol Dial Transplant 2012;27:3615-3620.

31 Bomback AS, Katz R, He K, Shoham DA, Burke GL, Klemmer PJ: Sugar-sweetened beverage consumption and the progression of chronic kidney disease in the Multi-Ethnic Study of Atherosclerosis (MESA). Am J Clin Nutr 2009;90:1172-1178.

-32 Lin J, Curhan GC: Associations of sugar and artificially sweetened soda with albuminuria and kidney function decline in women. Clin J Am Soc Nephrol 2011;6:160-166.

33 Brymora A, Flisinski M, Johnson RJ, Goszka G, Stefanska A, Manitius J: Low-fructose diet lowers blood pressure and inflammation in patients with chronic kidney disease. Nephrol Dial Transplant 2012;27:608-612.

-34 Krishnamurthy VM, Wei G, Baird BC, Murtaugh M, Chonchol MB, Raphael KL, Greene T, Beddhu S: High dietary fiber intake is associated with decreased inflammation and all-cause mortality in patients with chronic kidney disease. Kidney Int 2012;81:300-306. 
-35 Kendrick J, Cheung AK, Kaufman JS, Greene T, Roberts WL, Smits G, Chonchol M: Associations of plasma 25-hydroxyvitamin $\mathrm{D}$ and 1,25-dihydroxyvitamin D concentrations with death and progression to maintenance dialysis in patients with advanced kidney disease. Am J Kidney Dis 2012;60:567-575.

-36 Goraya N, Simoni J, Jo C, Wesson DE: Dietary acid reduction with fruits and vegetables or bicarbonate attenuates kidney injury in patients with a moderately reduced glomerular filtration rate due to hypertensive nephropathy. Kidney Int 2012;81:86-93.

- 37 Goraya N, Simoni J, Jo CH, Wesson DE: A comparison of treating metabolic acidosis in CKD stage 4 hypertensive kidney disease with fruits and vegetables or sodium bicarbonate. Clin J Am Soc Nephrol 2013;8:371-381.

- 38 Huang X, Jimenez-Moleon JJ, Lindholm B, Cederholm T, Arnlov J, Riserus U, Sjogren P, Carrero JJ: Mediterranean diet, kidney function, and mortality in men with CKD. Clin J Am Soc Nephrol 2013;8:1548-1555.

- 39 Ricardo AC, Madero M, Yang W, Anderson C, Menezes M, Fischer MJ, Turyk M, Daviglus ML, Lash JP: Adherence to a healthy lifestyle and all-cause mortality in CKD. Clin J Am Soc Nephrol 2013;8:602-609.

-40 Moranne O, Froissart M, Rossert J, Gauci C, Boffa JJ, Haymann JP, M'Rad MB, Jacquot C, Houillier P, Stengel B, Fouqueray B, NephroTest Study G: Timing of onset of CKD-related metabolic complications. J Am Soc Nephrol 2009;20:164-171.

-41 Eddington H, Hoefield R, Sinha S, Chrysochou C, Lane B, Foley RN, Hegarty J, New J, O’Donoghue DJ, Middleton RJ, Kalra PA: Serum phosphate and mortality in patients with chronic kidney disease. Clin J Am Soc Nephrol 2010;5:2251-2257.

42 Di Iorio B, Di Micco L, Torraca S, Sirico ML, Russo L, Pota A, Mirenghi F, Russo D: Acute effects of very-low-protein diet on FGF23 levels: A randomized study. Clin J Am Soc Nephrol 2012;7:581-587.

-43 Isakova T, Barchi-Chung A, Enfield G, Smith K, Vargas G, Houston J, Xie H, Wahl P, Schiavenato $\mathrm{E}$, Dosch A, Gutierrez OM, Diego J, Lenz O, Contreras G, Mendez A, Weiner RB, Wolf M: Effects of dietary phosphate restriction and phosphate binders on FGF23 levels in CKD. Clin J Am Soc Nephrol 2013;8:10091018.

-44 Cannata-Andia JB, Fernandez-Martin JL, Locatelli F, London G, Gorriz JL, Floege J, Ketteler M, Ferreira A, Covic A, Rutkowski B, Memmos D, Bos WJ, Teplan V, Nagy J, Tielemans C, Verbeelen D, Goldsmith D, Kramar R, Martin PY, Wuthrich RP, Pavlovic D, Benedik M, Sanchez JE, Martinez-Camblor P, Naves-Diaz M, Carrero JJ, Zoccali C: Use of phosphate-binding agents is associated with a lower risk of mortality. Kidney Int 2013;84:998-1008.

-45 Cozzolino M, Mazzaferro S, Brandenburg V: The treatment of hyperphosphataemia in CKD: calcium-based or calcium-free phosphate binders? Nephrol Dial Transplant 2011; 26:402-407.
46 Kidney Disease: Improving Global Outcomes (KDIGO) CKD-MBD Work Group: KDIGO clinical practice guideline for the diagnosis, evaluation, prevention, and treatment of chronic kidney disease-mineral and bone disorder (CKD-MBD). Kidney Int Suppl 2009; 113:S1-S130.

47 Lopes AA, Tong L, Thumma J, Li Y, Fuller DS, Morgenstern H, Bommer J, Kerr PG, Tentori F, Akiba T, Gillespie BW, Robinson BM, Port FK, Pisoni RL: Phosphate binder use and mortality among hemodialysis patients in the Dialysis Outcomes and Practice Patterns Study (DOPPS): evaluation of possible confounding by nutritional status. Am J Kidney Dis 2012;60:90-101.

48 Ciceri P, Elli F, Brenna I, Volpi E, Romagnoli S, Tosi D, Braidotti P, Brancaccio D, Cozzolino M: Lanthanum prevents high phosphateinduced vascular calcification by preserving vascular smooth muscle lineage markers. Calcif Tissue Int 2013;92:521-530.

-49 Block GA, Spiegel DM, Ehrlich J, Mehta R, Lindbergh J, Dreisbach A, Raggi P: Effects of sevelamer and calcium on coronary artery calcification in patients new to hemodialysis. Kidney Int 2005;68:1815-1824.

50 Toussaint ND, Lau KK, Polkinghorne KR, Kerr PG: Attenuation of aortic calcification with lanthanum carbonate versus calciumbased phosphate binders in haemodialysis: a pilot randomized controlled trial. Nephrology (Carlton) 2011;16:290-298.

-51 Kalil RS, Flanigan M, Stanford W, Haynes WG: Dissociation between progression of coronary artery calcification and endothelial function in hemodialysis patients: a prospective pilot study. Clin Nephrol 2012;78:1-9.

52 Block GA, Wheeler DC, Persky MS, Kestenbaum B, Ketteler M, Spiegel DM, Allison MA, Asplin J, Smits G, Hoofnagle AN, Kooienga L, Thadhani R, Mannstadt M, Wolf M, Chertow GM: Effects of phosphate binders in moderate ckd. J Am Soc Nephrol 2012;23:1407-1415.

53 Hill KM, Martin BR, Wastney ME, McCabe GP, Moe SM, Weaver CM, Peacock M: Oral calcium carbonate affects calcium but not phosphorus balance in stage 3-4 chronic kidney disease. Kidney Int 2013;83:959-966.

54 Chertow GM, Burke SK, Raggi P: Sevelamer attenuates the progression of coronary and aortic calcification in hemodialysis patients. Kidney Int 2002;62:245-252.

55 Spiegel DM, Brady K: Calcium balance in normal individuals and in patients with chronic kidney disease on low- and high-calcium diets. Kidney Int 2012;81:1116-1122.

56 Clinical practice guidelines for nutrition in chronic renal failure. K/DOQI, National Kidney Foundation. Am J Kidney Dis 2000; 35:S1-S140.
57 Carrero JJ, Stenvinkel P, Cuppari L, Ikizler TA, Kalantar-Zadeh K, Kaysen G, Mitch WE, Price SR, Wanner C, Wang AY, ter Wee P, Franch HA: Etiology of the protein-energy wasting syndrome in chronic kidney disease: a consensus statement from the International Society of Renal Nutrition and Metabolism (ISRNM). J Ren Nutr 2013;23:77-90.

58 Carrero JJ: Identification of patients with eating disorders: clinical and biochemical signs of appetite loss in dialysis patients. J Ren Nutr 2009;19:10-15.

59 Carrero JJ, Stenvinkel P: The vulnerable man: impact of testosterone deficiency on the uraemic phenotype. Nephrol Dial Transplant 2012;27:4030-4041.

-60 Cigarran S, Pousa M, Castro MJ, Gonzalez B, Martinez A, Barril G, Aguilera A, Coronel F, Stenvinkel P, Carrero JJ: Endogenous testosterone, muscle strength, and fat-free mass in men with chronic kidney disease. J Ren Nutr 2013;23:e89-e95.

61 Yilmaz MI, Sonmez A, Qureshi AR, Saglam M, Stenvinkel P, Yaman H, Eyileten T, Caglar K, Oguz Y, Taslipinar A, Vural A, Gok M, Unal HU, Yenicesu M, Carrero JJ: Endogenous testosterone, endothelial dysfunction, and cardiovascular events in men with nondialysis chronic kidney disease. Clin J Am Soc Nephrol 2011;6:1617-1625.

- 62 Kovesdy CP, George SM, Anderson JE, Kalantar-Zadeh K: Outcome predictability of biomarkers of protein-energy wasting and inflammation in moderate and advanced chronic kidney disease. Am J Clin Nutr 2009;90:407-414.

63 Lawson JA, Lazarus R, Kelly JJ: Prevalence and prognostic significance of malnutrition in chronic renal insufficiency. J Ren Nutr 2001;11:16-22.

-64 Sanches FM, Avesani CM, Kamimura MA, Lemos MM, Axelsson J, Vasselai P, Draibe SA, Cuppari L: Waist circumference and visceral fat in CKD: a cross-sectional study. Am J Kidney Dis 2008;52:66-73.

65 Campbell KL, Ash S, Davies PS, Bauer JD Randomized controlled trial of nutritional counseling on body composition and dietary intake in severe CKD. Am J Kidney Dis 2008: 51:748-758.

66 Amparo FC, Cordeiro AC, Carrero JJ, Cuppari L, Lindholm B, Amodeo C, Kamimura MA: Malnutrition-inflammation score is associated with handgrip strength in nondialysis-dependent chronic kidney disease patients. J Ren Nutr 2013;23:283-287.

-67 Fouque D, Kalantar-Zadeh K, Kopple J, Cano N, Chauveau P, Cuppari L, Franch H, Guarnieri G, Ikizler TA, Kaysen G, Lindholm B, Massy Z, Mitch W, Pineda E, Stenvinkel P, Trevino-Becerra A, Wanner C: A proposed nomenclature and diagnostic criteria for protein-energy wasting in acute and chronic kidney disease. Kidney Int 2008;73:391-398.

68 Kovesdy CP, Kopple JD, Kalantar-Zadeh K: Management of protein-energy wasting in nondialysis-dependent chronic kidney disease: reconciling low protein intake with nutritional therapy. Am J Clin Nutr 2013;97:1163-1177.
Modified GPS in Colorectal Cancer in the Era of Targeted Therapy
Nephron Clin Pract 2014;126:1-7 DOI: $10.1159 / 000357679$ 